\title{
THE RELATION BETWEEN THE OBJECTIVE OF WTO AND ECONOMIC RIGHTS
}

\author{
Intan Soeparna \\ Department of International Law, Faculty of Law, Universitas Airlangga \\ Researcher at Centre for Private and Economic Law, Vrije Universiteit Brussels \\ E mail: intan@fh.unair.ac.id
}

\begin{abstract}
WTO Members are obliged to provide trade rules and mechanism conducive for their citizens to conduct economy activities across frontier in order to pursue their economic interests. This obligation is based on economic right that is granted in their national constitutions. When the WTO Members implement its obligation under the WTO Agreements, they need to consider economic right as the main reason to involve in WTO. It is thus necessary to analyse the relation between the objective of WTO Agreements and economic rights, in order to seek the clarity of the primary intention of WTO Members to conduct international trade under the WTO Agreements. To this end, this article attempt to prove that there is a relation between WTO Objective and economic right in order to urge the WTO Members to imply the WTO Obligation based on economic rights that is granted in their constitutions.
\end{abstract}

Keywords: WTO objectives, economic rights and international trade

\begin{abstract}
Abstrak
Anggota WTO berkewajiban untuk mengatur ketentuan dan mekanisme perdagangan yang kondusif bagi warga negaranya dalam melakukan aktifitas ekonomi lintas negara dalam rangka memperoleh keuntungan ekonomi. Kewajiban ini berdasarkan hak ekonomi yang dijamin dalam konstitusi negaranegara anggota WTO. Ketika anggota WTO melaksanakan kewajiban berdasarkan Perjanjian WTO, mereka harus mempertimbangkan hak ekonomi sebagai alasan utama dalam bergabung dengan WTO. Oleh karena itu, perlu menganalisa hubungan antara tujuan Perjanjian WTO dan hak ekonomi dalam rangka menjelaskan tujuan anggota WTO melakukan perdagangan internasional. Untuk itu, artikel ini berusaha membuktikan bahwa terdapat hubungan antara tujuan WTO dan hak ekonomi dalam rangka mendorong anggota WTO melaksanakan kewajibannya berdasarkan hak ekonomi yang diatur dalam konstitusi mereka.
\end{abstract}

Kata Kunci: tujuan WTO, hak ekonomi dan perdagangan internasional

\section{Introduction}

In 1994, over one hundred governments took part in the Uruguay Round, defending the interests of countries of all sizes, stage of development and economic structures in World Trade Organization (WTO). All WTO Members brought their national economic interests and national trade policies into negotiation in Marrakesh. Furtherance in every WTO negotiation rounds, members are focusing on bargaining of trade obligations among them, the WTO therefore remains about multilateral and bilateral trade negotiation. These WTO Members are subject to trade obligations among them. However, WTO is not only accommodating obligations among members, but also accommodating the obligetions of government to its citizens. According to Panel in Section 301-310 of US Trade Act of 1974 case,

" $[t]$ he object and purpose of the Dispute Settlement Understanding (DSU), and the WTO more generally, that are relevant to a construction of Article 23, are those which relate to the creation of market conditions conducive to individual economy activity in national and global markets and to the provisions of a secure and pre- 
dictability multilateral trading system (emphasize added)."1

Panel emphasized that the obligation among WTO Members is driven by the obligation to create conducive market condition to individual economy activity both in national and global market, while this obligation is supported by economic rights that promulgated in each constitution of WTO Members.

Economic right is known as right granted by national constitution, but on the other side it is the obligation of government. This right is inherently accommodating individuals to pursue economic interest across frontier. In order to accommodate this right, a government is obliged to provide trade rules and mechanisms for its citizens to pursue their economic interests across frontier. It is thus necessary for a government to commit to preserve economic rights in the international scope by participating in international economic relation such WTO.

This article attempts to analyse the relation between the objective of WTO and economic right in order to seek the clarity of the primary intention of WTO Members to conduct international trade under the WTO, where WTO is not only consisting of obligation among members but also obligation from government to its citizen based on economic rights. To this end, the purpose of this article is to describe the importance of correlating the WTO Objective with economic right, in order to urge the WTO Members to imply the WTO Obligation based on economic rights that is granted in their constitutions.

\section{Discussion}

The WTO Law Consists of The Obligation of Government to Provide Trade Rules and Mechanisms for Individuals to pursue Economic Interests across Frontier

WTO, US: Section 301 - 310 of US Trade Act of 1974 Panel Report, (27 January 2000) WT/DS152/R, para. 7.71

2 Steve Charnovitz, "Economic and Social Actors in the World Trade Organization", ILSA Journal of International and Comparative Law, Vol. 7, No. 2, Spring 2001 edition, Florida: Nova South eastern University, page 259-274

WTO, US, Supra Note 1, para. 7.73

4 Cass R. Sunstein, "Why Does the American Constitution Lack Social and Economic Guarantees?", Syracuse Law
There are two layers of obligations in terms of WTO Agreements. First, it is obligations among the WTO Members (or obligations to individuals in other WTO Members jurisdiction), and second, it is the obligations from a government to individuals within its jurisdiction. ${ }^{2}$ The government is obliged to provide trade rules and mechanisms conducive for its citizens to conduct economy activity across frontier in order to pursue their economic interests. Panel also declared that "it would be entirely wrong to consider that the position of individuals is of no relevance to the GATT/WTO legal matrix. Many of the benefits to members which are meant to flow as a result of the acceptance of various disciplines under the GATT/WTO depend on the activity of individual economic operators in the national and global market places. The purpose of many of disciplines, indeed one of the primary objects of the GATT/WTO as a whole, it is to produce certain market conditions which would allow this individual activity to flourish." 3

The obligation of government to provide trade rules and mechanisms basically based on economic right that is granted by national constitution as a legal support and protection for individuals to conduct economic activities across frontier. Without legal support and protection from the government, including national and international legal support, these individuals find a paucity of economic benefits.

The Obligation of Government to Provide Trade Rules and Mechanisms for Individuals to pursue Economic Interest across Frontier based on Economic Rights according to Constitution

Economic rights exist in almost all modern national constitution in different phrases, ${ }^{4}$ such as economic freedom ${ }^{5}$, right to work $^{6}$, right to

Review Vol. 1 No. 56, January 2005 edition, New York: Syracuse University College of Law, page 1-17.

5 For example: Romanian Constitution Article 45, available at http://www.cdep.ro/pls/dic/site.page?id=371, Bulga rian Constitution Article 19, available at http://www. parliament.bg/en/const, Switzerland Constitution Article 27, available at https://www.admin.ch/ch/e/ rs/1/101.en.pdf

6 For example: Constitution of Norway Article 110, available at www.constitution.org/cons/norway/dok-bn. 
property $^{7}$, right to trade or to conduct business ${ }^{8}$, intellectual property rights ${ }^{9}$, and other right associate with economic activities. ${ }^{10}$ All these rights are foundation for all individuals to engage in any economic activities, such as activity to produce goods, to provide services, to sell and purchase goods, to distribute goods and services, and to own the property derives from any economic activities. ${ }^{11}$ The government is obliged to secure individual's economic rights in order to guarantee all individuals to pursue economic interests according to national constitution. ${ }^{12}$

States are aware to legitimate economic interest of their citizens in the constitution. For example, the EU Charter of Fundamental Rights contains few rights which can be clearly classified as modern and advanced economic rights. ${ }^{13}$ One of the prominent rights is property right which is recognised as the right of possession. ${ }^{14}$ Possessions are given a wide interpretation to include various assets acquired through economic activities. All vested rights having an economic value are included. The right is also including the means to earn an income from business. ${ }^{15}$ Through the protection of right to property, the EU Charter has certainly incorporated a wide

html, the EU Charter of Fundamental Rights Article 15, available at www.europarl.europa.eu/charter/pdf/text en.pdf, Constitution of Peru, Article 24, available at https://www.constituteproject.org/constitution/Peru_2 009.pdf, and Japan Constitution Article 27, available at japan.kantei.go.jp/constitution_and...of_japan/constit ution_e.html

7 For example: Japan Constitution Article 29, EU Charter of Fundamental Rights Article 14, and Argentine Constitution Section 17. Available at www.parliament.am/library /sahmanadrutyunner/argentina.pdf

8 For example: Commerce Clause and Contract Clause of the U.S. Constitution, available at www.archives.gov/ exhibits/charters/constitution_transcript.html, EU Charter of Fundamental Rights Article 16, Argentine Constitution Section 14, and Article 19 para. (g) in The Constitution Of India 1949.

9 For example: Article 1, Section 8, Clause 8 the U.S. Constitution,

10 For example: Article 33 of Indonesian constitution.

11 Ersnt-Urlich Petersmann, "Human Rights, International Economic Law and 'Constitutional Justice'", The European Journal of International Law Vol. 19 no. 4, September 2008 Edition, Oxford: Oxford University Press, page 769-798.

12 Ersnt-Urlich Petersmann, "WTO Constitution and Human Rights", Journal International of Economic Law, Vol 3, Issues 1, March 2000 edition, Oxford: Oxford University Press, page 19-25. range of economic activities within sphere of legal protection. The European Court of Justice (ECJ) has held that individuals obtain rights from the treaties creating the EU which are endowed with economic rights. This right, however, relates to the establishment of a common market area. ${ }^{16}$

The economic right is a foundation for government to provide a legitimate rule and mechanism for individual to pursue economic interest across frontier. For example, the regulation of market access in order to simplify access for citizens to conduct their economic activities across border. The higher level of government provides the necessary discipline and guarantee of market access, such as the economic liberty which is guaranteed as fundamental rights in Swiss Federal Constitution ${ }^{17}$, then in the regional level, the four fundamental freedoms are guaranteed by the EU law ${ }^{18}$, and in the global level like the WTO enshrines market access for individuals from all WTO Members.

The government commits to preserve individual's economic rights in the international scope by participating in international economic relation such WTO, because the core of intensive

13 Terence Daintith, "the Constitutional Protection of Economic Rights", International Journal of Constitutional Law, Vol. 2, No. 1, January 2004 Edition, Oxford: Oxford University Press and New York University School of Law, page 56 - 90.

14 European Charter of Fundamental Rights, art. 17, Available at http://fra.europa.eu/en/charterpedia/arti cle/17-right-property

15 Case V.D. Mussele v Belgium App no 8919/80 (ECHR 23 Nov 1983), Van Marlea.o. v Netherlands App no 8543/79; 8674/79; 8675/79; 8685/79 (ECHR 26 June 1986), and H v Belgium (30 Nov 1987 ) 10 E.H.R.R. 339.

16 Ernst-Urlich Petersmann, "Time for a United Nations 'Global Compact' for Integrating Human Rights into the Law of Worldwide Organizations: Lessons from European Integration", European Journal of International Law Vol. 13 Issue 3, April 2002, Oxford: Oxford University Press, page 621-650.

17 Switzerland Constitution, Article 27, Economic Freedom, Available at: http://www.servat.unibe.ch/icl/sz00000 _.html

18 Market Access right for goods is promulgated in Free Movement of Goods, Treaty Functioning of European Union (Treaty Rome) Articles 28 - 37, available at: http: //eurlex.europa.eu/LexUriServ/LexUriServ.do?uri=OJ:C: 2008:115:0047:0199:en:PDF; See also Hans-Werner Sinn, "EU Enlargement and the Future of the Welfare State", Scottish Journal of Political Economy, Vol. 49, Issue 1, February 2002, Hoboken: Blackwell Publishing, page 104115. 
international economic relations begins with individual economic interest. Historically, Voitovich gave his statement that created international economic relation. According to him "the global economic relation derives from common interest of states which is influenced by individual economic interest within the country, to meet this common economic interest, states therefore construct extraterritorial economic agreement which is creating international legal rules." ${ }^{19}$ Van Themaat also posited that "interdependency of states in economic activity is obvious to realise the objective of national economic interest, since historically at national level in the west, that is no longer possible to achieve a number of objectives of national economic policy through national means only. It is thus necessary to have international intervention in addition to international rules for liberalisation and non-discrimination simply for realisation of the objective of national economic interest." 20 It can also be concluded from the main point of GA Resolution 1974 that the national economic interest is genuinely representing the individual economic interest that could be the primary reason to commit to international economic law in the sphere of development of cross border economic activities. Significantly, the motivation behind any international economic law is the intention of a state to enhance its individuals to gain a broader benefit. ${ }^{21}$ In the particular contemporary world, the closer relationship between international norms and domestic norms, tend to make international economic relations affects citizens. As the world becomes more economically interdependent, the citizens thus will more find greater possibility to conduct their business and to provide better income that is affecting their quality of life. The result of this, citizens of the country could be expected to assert them in more aggressive and require their government to respond

19 Sergei A Voitovich, 1995, International Economic Organizations in the International Legal Process Vol.18, Leiden: Martinus Nijhoff Publisher, page 4

20 Pieter Verloren VanTheemat, 1981, The Changing Structure of International Economic Law, Leiden: Martinus Nijhoff Publisher, page 15-16

21 GA Res. 3281(xxix), UN GAOR, 29th Sess., Supp. No. 31 (1974) 50, Charter of Economic Rights and Duties of their needs to a greater extent in development of international economic relations. To that end, the intention of a government to join the WTO is to support its individuals to gain a broader economic benefit based on their economic rights.

The Commitment of Government to join the WTO is to Guarantee Individual's Economic Rights

The key objective of WTO law is the progressive removal of barriers that prevent or make more difficult beneficial exchange between producers and consumers located in different countries. The removal of barriers intends to enhance support that the WTO promotes growth and economic stability, in turn to support the protection of economic rights for individual. ${ }^{22}$ All WTO Members is adopting WTO rules based on mandate from their constitutions to guarantee economic rights of individual, indirectly the corresponding to individual right hence exists in the coherence context between the intention of the states to join the WTO and their obligations to guarantee economic rights.

Although WTO and GATT do not contain economic rights, but WTO law regulates precise rule of non-discrimination in the sense of most favoured nation treatment and national treatment which is very significant to guarantee functions with regard to the safeguarding of unimpeded trade. The economic rights that are underlying in national constitution of each WTO Member become a main purpose for all individual to involve in international trade. In the light of it, when WTO creators negotiated multilateral trading system, they created objective of WTO in accordance with economic right of individual. The government of WTO Members therefore relies on this objective in regard to provide trade rules and mechanisms for individual to trade across border. In order to support the argument

States, Article 5, available at: http://www.un-docu ments.net/a29r3281.htm.

22 Robert D Anderson and Hannu Wager, "Human Rights, Development, and the WTO: the Case of Intellectual Property and Competition Policy", Journal of International Economic Law. Vol. 3 No 9, August 2006 edition, Oxford: Oxford University Press, page 740 
above, the following sub section discusses an analytical approach of the objective of the WTO and its relation to economic rights.

\section{The Relation between the Objective of the WTO and Economic Rights}

The Preamble of the WTO Agreements underlines that Members are

"Recognizing that their relations in the field of trade and economic endeavour should be conducted with a view to raising standards of living, ensuring full employment and a large and steadily growing volume of real income and effective demand, and expanding the production of and trade in goods and services, while allowing for the optimal use of the world's resources in accordance with the objective of sustainable development, seeking both to protect and preserve the environment and to enhance the means for doing so in a manner consistent with their respective needs and concerns at different levels of economic development". ${ }^{23}$

The main objective of the WTO is "to raising standard of living, ensuring full employment and a large and steadily growing volume of real income and effective demand, and expanding the production of good and services". ${ }^{24}$ It elaborates the relation between the existent of individual right to raise standard of living and full employment underlines in WTO and the economic activity of individual as an engine for such economic growth. The success of the WTO to increase the world's economic welfare depends on a considerable extent of individuals initiatives. The objective of the WTO of increasing human welfare with an open trading system that fosters employment and development at the same time requires and promotes individual freedom and economic rights. Economic rights serve trade interest because they enhance economic potential

23 Peter van den Bossche and Werner Zdouc, 2013, The Law and Policy of the World Trade Organization: text, cases and material, Cambridge: Cambridge-university Press, page 82

24 WTO:US, Supra Note 1, Section (c ), para. 7.74.

25 Jakob de Haan, Susanna Lundstrom, and Jan Egbert Strum, "Market-Oriented Institutions and Policies and Economic Growth: A Critical Survey", Journal of Economic Surveys Vol. 20 No.2, April 2006 Edition, Sussex: John Willey Itd, page 157-191. and protect economic freedom as it underlines in the concept of economic freedom. ${ }^{25}$

The Achievement of Trade and Economic Endeavour should be Conducted with a view to Raising Standards of Living

The WTO law is trade rules and mechanisms for individuals to conduct trade across frontier that are negotiated by their governments. These trade rules and mechanisms are created based on the intention of all WTO Members to conduct trade and economic activities with a view to raise standards of living for all individuals by expanding trade in goods and services and reducing barriers to trade. ${ }^{26}$

Tariff concession and non-trade barriers consider as rules that are provided for individuals to simplify their economic activities across border. ${ }^{27}$ With these rules, they are supposed to pursue economic interest while their governments are supporting it through constitutional commitment to protect right to obtain profit from economic activity. One of significant economic rights is right to property. This right becomes a major intention for each nation to involve in the WTO. The establishment of secure and stable right to property has become a key element in the rise of modern economic growth. It stands to reason that individuals would not have the incentive to accumulate and innovate unless they had adequate control over the return to the assets that are thereby produced or improved, and at the end individuals have rights to enjoy the benefit from it.

In relation with the objective of the WTO, the protection of property right will elevate the full raising of standard of living when individual has right to obtain and enjoy benefit from their economic activity, without any restriction or deprivation from national policy. ${ }^{28}$ The objective

26 Interpretation of WTO Objective by Panel in Ecuador: Bananas III - Recourse to Appellate Body Under Article 21.5, (26 November 2008) WT/DS27/AB/RW2/ECU, US: EC - Bananas III Recourse to Appellate Body under Article 21.5, (19 May 2008) WT/DS27/RW/USA, para. 433

27 P.J. Lloyd, "The Architecture of WTO", European Journal of Political Economy, Vol. 17 Issue 2, June 2001, Amsterdam: Elsevier Publisher, page 327-353.

28 See Opinion of Advocate General Siegbert Alber in Cases C-93/02 $P$ and C-94/02 P, Biret International SA and 
of the WTO accommodates the promotion of rights lie exclusively in the international economic sphere, such as the rights of exporters and importers to enjoy the property, freedom of contract, non-discrimination in relation to other like industries, and freedom of movement goods and services across border.

European Union (EU) had experience regarding the consequence of violating WTO Agreements when the violation is deemed as an infringement of individual's economic right. In Biret case, Biret Company claimed to have suffered damage as a consequence of EU Legislation prohibiting the importation of hormone treated meat. ${ }^{29}$ Biret referred to the WTO Dispute Settlement Body (DSB) Decision in Hormone Case ${ }^{30}$ that EU Ban on imports of meat and meat products from cattle treated with any of six specific hormones for growth promotion purposes was inconsistent with the provisions of the SPS Agreement, and required EU to lift the hormone ban in the absence of any scientific risk assessment of harm. ${ }^{31}$ Biret also sought compensation for damage because the ban was violating their rights to conduct business. However, EU General Court (GC) rejected the claim for damage because the Court did not identify the unlawful conduct of EU. The court also denied the possibility for individuals to rely on provision of the WTO Agreement in order to rectify their economic rights that is violated.

General Advocate Alber in Biret Case argued that the Court's reasoning to refuse to comply with the DSB Decision is infringing fundamental right or economic right. ${ }^{32}$ Biret Company can-

Etablissements Biret et Cie. SA v Council of the European Union, in EU Press Release, CJE/03/39, (15 May 2003), page 120

29 Patricia Egli, "Biret International SA v. Council of the European Union. Case C-93/02 P. 2003 ECR I-10497; Établissements Biret \& Cie SA v. Council of the European Union. Case C-94/02 P. 2003 ECR I-10565", The American Journal of International Law, Vol. 99, No. 1, January 2005, Washington: American Society of International Law Publisher, page 230-235.

30 WTO, EC: Hormone case, (19 February 1997) WT/DS26/ 13.

31 WTO: EC-Hormones case-complaint by the US, WT/DS26/ R/USA and EC-Hormones (complaint by Canada), WT/ DS48/R/CAN, (18 August 1997). EC: Hormone CaseAppellate Body Report (16 January 1998) WT/DS/26/ $A B / R$ and $W T / D S 48 / A B / R$. not continue its normal commercial activity because the EU has decided not to comply with WTO law which is affecting its business and the economic right is affected in its core. ${ }^{33}$ The EU made restriction on trade through the adoption of SPS measures which was in discrimination between domestic and imported goods and those who engaged in trade such goods. Restriction on trade therefore affects the citizen's freedom to pursue an economic activity. Meanwhile, the SPS Agreement is of considerable important to citizens to engage in trade as it regulates in Article 2 (3) that this agreement intends to prevent a disguise restriction on international trade. ${ }^{34}$ To this end, the hormone ban that restricts Biret Company to conduct its economic activity under the SPS Agreement is infringing the right to pursue economic activity which is granted by the EU Charter Article 16 (freedom to conduct a business) and Article 17 (right to property) while basically Biret Company has inviolable right to trade protection under EU Charter.

\section{Full Employment}

The WTO negotiator also created rules and mechanisms which are relating to employment. ${ }^{35}$ For example, the GATT has several provisions relating to employment, such as GATT Article XII: (3) para. (a), mentions that 'contracting parties undertake, in carrying out their domestic policies, to pay due regard to the need for maintaining or restoring equilibrium in their balance of payment on a sound and lasting basis and to the desirability an uneconomic employment of productive resources.' This article relates to do-

32 Alberto Alemanno, "Judicial Enforcement of the WTO Hormones Ruling Within the European Community: Toward EC Liability for the Non-Implementation of WTO Dispute Settlement Decisions?", Harvard International Law Journal, Vol. 45, Issue 2, July 2004, Massachusetts: Harvard University Press, page 560.

33 Marco Bronckers and Sophie Goelen, "Financial Liability of the EU for Violations of WTO Law: A Legislative Proposal Benefiting 'innocent Bystanders'”, Legal Issues of Economic Integration Vol. 39, Issue 4, June 2012, Oxford: Oxford University Press, page 399-418.

34 Opinion AG Alber, Supra Note 28, para 117.

35 Steve Charnovitz, "the (Neglected) Employment Dimension of the World Trade Organization", Working Paper of the George Washington University Law school, Public Law and Legal Theory, No. 131, April 2006. Washington: George Washington University Press, page 1-35. 
mestic policies directed toward the achievement and maintenance of 'full and productive employment'. ${ }^{36}$

Employment dimension also plays a role in other WTO Agreements, for example in Agreement on Subsidies and Countervailing Measures (SCM Agreement), Article 15 (4). According to this article, the examination of the impact of the subsidized imports on the domestic industry shall include an evaluation of all relevant economic factors and indices having a bearing on the state of the industry, including employment. ${ }^{37}$ Agreement on Textiles and Clothing, Article 6 (3), also regulates a standard examination of the effect on import that is able to relate to employment. ${ }^{38}$ The most profound agreement regarding the employment is GATS Article V bis: Labour Markets Integration Agreement. It states that WTO Agreements shall not prevent any of its members from being a party to an agreement establishing full integration of the labour markets between or among the parties. Another rule regarding the employment is GATS Annex on Movement of $\mathrm{Na}$ tural Persons Supplying Services. This annex applies to measures affecting natural persons who are services suppliers of a member, and natural persons of a member who are employed by a services supplier of a member. ${ }^{39}$

The context of full employment is pertinent to economic rights which constitutes as foundation for all individuals to earn personal income derives from their economic activities. $\mathrm{Na}$ tional trade policy should not deprive this right since it is essential for all individuals in or-der to gain the benefit from trade across frontier according to WTO law.

36 General Agreement on Tariffs and Trade 1947, (15 April 1994), LT/UR/A-1A/1/GATT/2, (https://docs.wto.org/)

37 Agreement on Subsidies and Countervailing Measures, (15 April 1994), LT/UR/A-1A/9, (https://docs.wto.org/)

38 Agreement on Textiles and Clothing, (15 April 1994), LT/UR/A-1A/11, (https://docs.wto.org/)

39 General Agreement on Trade in Services, (15 April 1994), LT/UR/A-1B/S/1, (https://docs.wto.org/)

40 Ernst-Ulrich Petersmann, "Human Rights, International Economic Law and Constitutional Justice: A Rejoinder", the European Journal of International Law, Vol. 19 No. 5, November 2008 Edition, Oxford: Oxford University Press, page 955-960.

41 WTO, US: Supra Note 1, para. 7.75 - 7.76. See also WTO: Japan-Taxes on Alcoholic Beverages-Appellate Body report, (4 October 1996) WT/DS8/AB/R,WT/DS10/AB/R,

\section{Trade security and predictability}

The WTO Member should take necessary measure to provide stability and predictability of trade mechanism in order to secure individual economic right related to trade or business. ${ }^{40} \mathrm{It}$ is also relating to achieve the broad objective of the WTO Agreements, as declared by Panel in Section 301-310 of US Trade Act of 1974 Case that

"the multilateral trading system is, per force, composed not only of States but also, indeed mostly, of individual economic operators. The lack of security and predictability affects mostly their individual operators. Hence, providing security and predictability to multilateral trading system is another central object and purpose of the trade system which could be instrumental to achieve the broad objective of the WTO Agreements." 41

In the case of Argentina - Measures Affecting Imports of Footwear, Textiles, Apparel and Other Items, the Government of Argentina concerns to provide stability and predictability of trade mechanism which is promulgated under the Law No. 22.415 whereby importers have procedural right to challenge any duties assessed beyond the bound rate which purportedly a part of Argentine Law. ${ }^{42}$ This procedural right derives from right to trade and to conduct business underlined in Argentina Constitution. ${ }^{43}$ In this settled case, Argentina also stated that the stability and predictability of concessions in it schedule commitments were supported by Section $75 \mathrm{~Pa}$ ragraph 22 of the Argentina Constitution of

and WT/DS11/AB/R. WTO: India-Patent Protection for Pharmaceutical and Agricultural Chemical ProductsAppellate Body Report (19 December 1997), WT/DS50/ AB/R. WTO, Argentina: Measures Affecting Imports of Footwear, Textiles, Apparel and Other Items - Panel Report , (25 November 1997), WT/DS56/R, para 6.29

42 WTO, Argentina: Measures Affecting Imports of Footwear, Textiles, Apparel and Other Items - Panel Report (25 November 1997) WT/DS56/R, para. 3.215 - 3.217. see also J Lacarte-Muró and P Gappah Z, "Developing countries and the WTO legal and dispute settlement system: a view from the bench", Journal International of Economic Law, Vol. 3 Issue 3, September 2000, Oxford: Oxford University Press, page 395-401.

43 Constitution of the Argentine People, Section 14, available at: (http://www.senado.gov.ar/) 
1994. ${ }^{44}$ These commitments were at the top of the legal hierarchy and, therefore, took precedence over domestic legislation. All judges in Argentina have power to declare, at the request of an interest party, the unconstitutionally of any measures adopted in breach of rules contain in an international treaty, such as WTO Agreements. ${ }^{45}$

\section{Closing}

\section{Conclusion}

WTO law is not only about rights and obligations to conduct international trade among members, but also commitment from a government to provide market conditions conducive to individual economy activity in national and global markets. This commitment is conceivable to support individual to achieve better income and benefit, to promote positive result of enhancing welfare and full employment based on economic rights that is granted by national constitution. Although WTO does not regulate economic rights directly, but the Members of WTO negotiated WTO Rules and Mechanism in accordance with economic rights that is embodied in the objecttive of WTO Agreements. The relation between objective of WTO and economic rights is that those WTO Members have primary intention to conduct international trade in order to support its citizen to gain economic benefits based on economic rights. It is significantly seen in the context of objective of WTO that raising standard of living and full employment become primary concern for WTO Members to conduct international trade under the WTO Agreements.

However, WTO Member, such EU, sometimes finds paucity to imply the WTO obligation merely based on economic rights since international trade cost much more than legal obligation between EU and its citizen. It is thus necessary for EU Court to rely on the objective of WTO in order to support its citizen to engage in international trade based on their economic rights. On the other hand, another WTO Member, such Argentina, has commitment in preserving

44 Ibid, Chapter IV, Powers of Congress, Section 75, para. 22. economic rights as a main reason to involve in WTO as it promulgates in the Argentine Constitution. Its constitution declares that the right to trade and to conduct business as a part of economic right take precedent over the implementation of WTO obligations.

\section{Suggestion}

The main intention of WTO Members to involve in WTO is to provide better trade mechanism in order to support their citizens to conduct trade across frontier. The Government can support its citizens by granting economic rights based on its constitutions. It means that any trade policy cannot diminish this inviolable right when the government implying WTO obligations. It is hence significant that correlating the WTO Objective with economic right will urge the WTO Members to implement the WTO Obligation merely based on economic rights. Such in Biret Case, AG Alber argued that EU Court must not disregard the freedom of trade and freedom to pursue economic activity, when Biret Company sought compensation for damage due to the violation of its economic right. The EU Court needs to consider that the economic rights and liberty derives from national law of each WTO Members become a main purpose for all indivi-dual to involve in the international trade, since the accession to WTO Agreement contains several possibilities for individuals to gain their economic interest.

\section{References}

Alemanno, Alberto. "Judicial Enforcement of the WTO Hormones Ruling Within the European Community: Toward EC Liability for the Non-Implementation of WTO Dispute Settlement Decisions?". Harvard Interna-tional Law Journal. Vol. 45. Issue 2. July 2004. Massachusetts: Harvard University Press;

Anderson, Robert D. and Wager. Hannu. "Human Rights. Development. and the WTO: the Case of Intellectual Property and Competition Policy". Journal of International Economic Law. Vol. 3 No 9. August 2006. Oxford: Oxford University Press; 
Bossche, Peter van den. and Zdouc. Werner. 2013. The Law and Policy of the World Trade Organization: text. cases and material. Cambridge: Cambridge-university Press;

Bronckers, Marco and Goelen. Sophie. "Financial Liability of the EU for Violations of WTO Law: A Legislative Proposal Benefiting 'innocent Bystanders'”. Legal Issues of Economic Integration. Vol. 39. Issue 4. June 2012. Oxford: Oxford University Press;

Bulgarian Constitution available at http://www. parliament.bg/en/const. Accessed on August 2015;

Charnovitz, Steve. "Economic and Social Actors in the World Trade Organization". ILSA Journal of International and Comparative Law. Vol. 7. No. 2. Spring 2001. Florida: Nova South eastern University;

Charnovitz, Steve. "the (Neglected) Employment Dimension of the World Trade Organization". Working Paper of the George Washington University Law school. Public Law and Legal Theory. No. 131. April 2006. Washington: George Washington University Press;

Commerce Clause and Contract Clause of the U.S. Constitution. available at www. archives.gov/exhibits/charters/constituti on_transcript.html. accessed on September 2015;

Constitution of Norway available at www. constitution.org/cons/norway/dok-bn. html. accessed on August 2015;

Constitution of Peru. available at https://www. constituteproject.org/constitution/Peru_ 2009.pdf. accessed on August 2015;

Daintith, Terence. "the Constitutional Protection of Economic Rights". International Journal of Constitutional Law. Vol. 2. No. 1. January 2004. Oxford: Oxford University Press and New York University School of Law;

Egli. Patricia, "Biret International SA v. Council of the European Union. Case C-93/02 P. 2003 ECR I-10497; Établissements Biret \& Cie SA v. Council of the European Union. Case C-94/02 P. 2003 ECR I-10565". the American Journal of International Law. Vol. 99. No. 1. January 2005. Washington: American Society of International Law Publisher;
European Charter of Fundamental Rights. Available at http://fra.europa.eu/en/charter pedia/article/17-right-property. accessed on September 2015;

Haan, Jakob de. Lundstrom. Susanna and Strum. Jan Egbert. "Market-Oriented Institutions and Policies and Economic Growth: A Critical Survey". Journal of Economic Surveys. Vol. 20 No.2. April 2006. Sussex: John Willey ltd;

Japan Constitution. available at japan.kantei. go.jp/constitution_and...of_japan/constit ution_e.html. accessed on August 2015;

Lloyd. P.J. "The Architecture of WTO". European Journal of Political Economy. Vol. 17. Issue 2. June 2001. Amsterdam: Elsevier Publisher;

Muró, J Lacarte-. and Z. P Gappah. "Developing countries and the WTO legal and dispute settlement system: a view from the bench". Journal International of Economic Law. Vol. 3 Issue 3. September 2000. Oxford: Oxford University Press;

Opinion of Advocate General Siegbert Alber in Cases C-93/02 P and C-94/02 P. Biret International SA and Etablissements Biret et Cie. SA v Council of the European Union. in EU Press Release. CJE/03/39. (15 May 2003);

Petersmann, Ernst-Ulrich. "Human Rights. International Economic Law and Constitutional Justice: A Rejoinder". the European Journal of International Law. Vol. 19 no. 5. November 2008. Oxford: Oxford University Press;

"Time for a United Nations 'Global Compact' for Integrating Human Rights into the Law of Worldwide Organizations: Lessons from European Integration". European Journal of International Law. Vol.13 Issue 3. April 2002. Oxford: Oxford University Press;

"WTO Constitution and Human Rights". Journal International of Economic Law. Vol. 3 Issues 1. March 2000. Oxford: Oxford University Press;

-.-.-.. "Human Rights. International Economic Law and 'Constitutional Justice'". the European Journal of International Law. Vol. 19 No. 4. September 2008. Oxford: Oxford University Press; 
Romaian Constitution available at http://www. cdep.ro/pls/dic/site. page?id=371. accessed on August 2015;

Sinn, Hans-Werner. "EU Enlargement and the Future of the Welfare State". Scottish Journal of Political Economy. Vol. 49. Issue 1. February 2002. Hoboken: Blackwell Publishing;

Sunstein, Cass R. "Why Does the American Constitution Lack Social and Economic Guarantees?". Syracuse Law Review. Vol. 1 No. 56 January 2005. New York: Syracuse University College of Law;

Switzrland Constitution. Economic Freedom. Available at: http://www.servat.unibe. ch/icl/sz00000_.html. accessed on September 2015;

The EU Charter of Fundamental Rights available at www.europarl.europa.eu/charter/pdf / text_en.pdf. accessed on August 2015;

Theemat, Pieter Verloren Van. 1981. The Changing Structure of International Eco-nomic Law. Leiden: Martinus Nijhoff Publisher;

Voitovich, Sergei A. 1995. International Economic Organizations in the International Legal Process. Vol. 18. Leiden: Martinus Nijhoff Publisher. 